\title{
REVIEW
}

\section{The non- $H$ pylori helicobacters: their expanding role in gastrointestinal and systemic diseases}

\section{J G Fox}

Gut 2002;50:273-283

The number of species in the genus Helicobacter has rapidly expanded over the past decade. The genus now includes at least 24 formally named species as well as numerous other helicobacters awaiting formal naming. This review highlights the expanding role that other helicobacters, although not as well known as $\mathrm{H}$ pylori, play in gastrointestinal and systemic disease in humans.

T he number of species in the genus Helicobacter has rapidly expanded during the past decade. Today, at least 24 formally named helicobacters have been identified and an additional 35 or more novel helicobacters await formal naming. Of the gastric helicobacters, Helicobacter pylori is the best known and the most important in terms of global impact on human disease. However, two other gastric helicobacters, $H$ heilmannii and $H$ felis, are associated with gastric disease in humans and are worthy of discussion. ${ }^{12}$ Nineteen named species colonise the lower intestinal tract of animals, many of which also colonise humans (table 1). These helicobacters which naturally colonise the intestinal crypts and are often associated with diarrhoea, can cause bacteraemia and systemic disease including colonisation of the biliary tract and induction of cholecystitis and hepatitis (and in some cases hepatic cancer). Immunocompromised hosts are particularly susceptible to these microaerobic organisms..$^{3-7}$ Eight of these enterohepatic helicobacters ( $H$ canis, $H$ pullorum, $H$ cinaedi, $H$ fennelliae, $H$ canadensis, $H$ winghamensis, $H$ westmeadi, and $H$ rappini) have been isolated from diarrhoeic and/or bacteraemic humans (table 2). Some of the species may also have zoonotic potential. $H$ heilmannii and $H$ felis are associated with gastritis in a variety of animals, including humans. $H$ pullorum has been isolated from humans and poultry, $H$ canis from dogs, cats, and humans, $H$ cinaedi from humans, non-human primates, dogs, and hamsters, and "H rappini" from dogs, cats, mice, humans, and non-human primates. The purpose of this review is to highlight the expanding role that other helicobacters, although not as well known as $H$ pylori, play in gastrointestinal and systemic disease in humans.

Grox, Division of Comparative Medicine, Massachusetts Institute of Technology, 77 Massachusetts Avenue, Bldg. 16, Rm. 825C

Cambridge, MA 02139 USA; igfox@mit.edu

Accepted for publication 30 August 2001

\section{HISTORICAL PERSPECTIVE} Early descriptions of the non- $H$ pylori gastric organisms: $\boldsymbol{H}$ felis, $\boldsymbol{H}$ heilmannii (bizzozeronii), "Flexispira rappini"

Gastric spiral shaped microorganisms have been noted in animals and humans for more than a century. Rappin in 1881 and Bizzozero in 1893 are credited with the first observations of gastric spiral shaped bacteria in animals. Salomon in 1896 reported spiral organisms in the stomachs of dogs, cats, and the brown Norway rat, but none in humans, monkeys, cattle, pigs, mice, pigeons, or crows. ${ }^{8}$ Others recorded $100 \%$ prevalence of spiral organisms in the stomachs of dogs, cats, and rhesus monkeys. Because many of the helicobacters observed in the stomachs of animals have been isolated only recently, earlier papers describing these bacteria were based on morphological criteria. Three morphological forms of these organisms were reported in dogs by Lockard and Boler. ${ }^{9}$ All three of these morphologically distinct organisms are now known to be Helicobacter spp by 16S rRNA analysis and the early descriptions provided by these authors have been useful for identifying and studying similar gastric bacteria in animals and humans.

Lockard type 1 (now known as "H rappini" taxa) is a bacterium entwined with periplasmic fibres which appear to cover the entire surface of the organism (fig 1). ${ }^{9}$ Bryner et al isolated a similar organism from aborted ovine fetuses and classified the organism as "Flexispira rappini". ${ }^{10}$ It is now known that this organism is a Helicobacter species. "Flexispira rappini" experimentally produces abortion in guinea pigs and sheep as well as hepatitis in aborted fetuses. It has also been isolated from the intestines of a variety of animals and humans. ${ }^{10}{ }^{11}$ Lockard bacterium type 2 also has periplasmic fibres but they are sparsely distributed on the organism and can appear singly or in groups of two, three, or four. This bacterium, which measures $0.4 \times 5-10 \mu \mathrm{m}$, has been cultured from the stomachs of cats, dogs, and humans and has been named $H$ felis. ${ }^{12}$ The third morphologically distinct organism, type 3 , is the bacteria most commonly seen in animal stomachs (dogs, cats, non-human primates, cheetahs, swine) and occasionally in human stomachs. This bacterium, although very tightly spiralled, does not have periplasmic fibres. The organism has been given various names- "Gastrospirillum hominis", "H heilmannii" and most recently has been cultured from dogs and named $H$ bizzozeronii (fig 2). ${ }^{13}$ This bacterium measures $0.3 \times 5-10 \mu \mathrm{m}$ and

Abbreviations: $\mathrm{PCR}$, polymerase chain reaction; $\mathrm{CLOs}$, campylobacter-like organisms; HLOs helicobacter-like organisms; CDT, cytolethal distending toxin; RFLP, restriction fragment length polymorphism; HIV, human immunodeficiency virus; XLA, X linked agammaglobulinaemia; PSC, primary sclerosing cholangitis. 


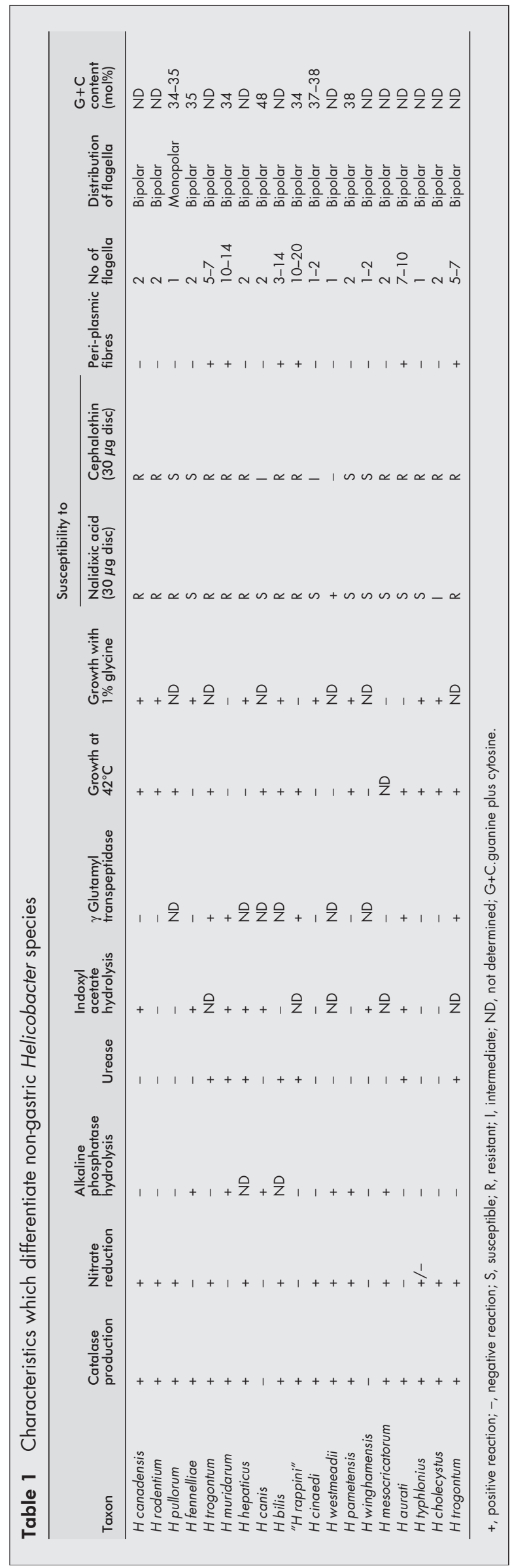

has 10-20 sheathed flagella at both ends of the cell. Helicobacter spp have also been cultured from the stomachs of ferrets, non-human primates, cheetahs, dolphins, whales, and mink.

Early descriptions of enterohepatic Helicobacter spp Spiral motile bacteria have evolved to inhabit the mucus of the intestinal crypts. The best known of these spiral microaerobic organisms is Campylobacter jejuni. We now recognise that the intestinal crypts of a variety of animals, as well as humans, are also the natural reservoir of many members of the genus Helicobacter. In early studies on lower bowel flora of rodents, Davis et al, using electron microscopy, described what is now known as distinct species of helicobacters. The most clearly recognisable form (fusiform to spiral and entwined by periplasmic fibres) belonged to the diverse taxa of " $\mathrm{H}$ rappini" which includes $H$ bilis and $H$ trogontum (fig 3). ${ }^{41}$ Indeed, organisms with this same morphology have been noted by electron microscopy in the bowel of humans and the inflamed colon of cotton top tamarins suffering from ulcerative colitis. ${ }^{1516}$

Members of the second type that was commonly noted by electron microscopy resembled campylobacters but were longer and had bipolar sheathed flagella. These were most likely representative of several species of human as well as rodent helicobacters with this morphology-for example, $H$ hepaticus (fig 4), H typhloclonus, or those with unsheathed flagella-being consistent with the morphology of $H$ rodentium. Rodent helicobacters, particularly $H$ hepaticus and $H$ bilis, which persistently colonise their hosts, have been linked to both chronic hepatic and intestinal disease and are increasingly being used in mouse models to understand the pathogenesis of Helicobacter induced gastrointestinal disease. $^{3417}$

\section{ISOLATION OF FASTIDIOUS ENTEROHEPATIC AND NON-H PYLORI GASTRIC HELICOBACTER SPP}

Many hospital laboratories may have difficulty in isolating enteric helicobacters. Because of the slow growth of helicobacters under microaerobic conditions, an accurate diagnosis is unlikely if blood culture procedures which rely on visual detection of the culture media are utilised. ${ }^{18} 19$ Dark field microscopy or use of acridine orange staining of blood culture media, rather than Gram staining, increases the likelihood of visualising the organism.

Selective antibiotic media are routinely used if faecal specimens are being processed. However, several strains of both $H$ cinaedi and $H$ fennelliae are inhibited by concentrations of cephalothin and cetazolin used frequently in selective media for isolation of enteric microaerobic bacteria. ${ }^{19}$ Alternatively, recovery is facilitated by passing faecal homogenates through a $0.45 \mu \mathrm{m}$ filter. ${ }^{20} \mathrm{H}$ cinaedi and $H$ fennelliae can grow under anaerobic conditions but this anaerobic growth may be only under laboratory conditions where the organisms have adapted to the controlled anaerobic environment. For the best recovery of enterohepatic helicobacters, faecal or intestinal biopsy samples should be placed in $20 \%$ glycerol medium for transportation. Higher $\mathrm{H}_{2}$ levels (5-10\%) are required for optimal enteric Helicobacter spp isolation. Unfortunately, this atmosphere is not available in the commercially available diagnostic kits used for Campylobacter isolation.

It also has been suggested by several investigators that the true prevalence of $H$ pullorum in both chickens and as a purported cause of gastroenteritis in humans may be under reported because of the difficulties associated with isolation and species identification. ${ }^{21} H$ pullorum is sensitive to polymyxin which is used in Skirrow selective media for isolation of CLOs; its use for isolation of H pullorum is therefore not warranted. Like many helicobacters, $H$ pullorum is inert in most biochemical tests commonly used in diagnostic laboratories and even when isolated on bacterial media may be easily 
Table 2 Non-Helicobacter pylori helicobacters isolated from humans (as of 2001)

\begin{tabular}{|c|c|c|c|c|}
\hline Species & Other hosts & Primary site & Other sites & References \\
\hline "H rappini" * & Sheep, dog, mice & Intestine & Blood (humans); liver (sheep); stomach (dogs) & $9,56,60,82,124$ \\
\hline$H$ canis* & Dog, cat & Intestine & Blood (humans); liver (dog) & $24,52-54$ \\
\hline$H$ cinaedi* & Hamster, rhesus monkey, dog & Intestine & Blood, soft tissue, joints (humans); liver (monkey) & $20,40-44$ \\
\hline H fennelliae & Dog, macaque & Intestine & Blood & $18,37,38$ \\
\hline H pullorum* & Chicken & Intestine & Liver (chicken) & 61,62 \\
\hline$H$ canadensis & $\mathrm{NR}^{* *}$ & Intestine & NR & 33 \\
\hline $\mathrm{H}$ westmeadii & NR & NR & Blood & 76 \\
\hline$H$ winghamensis & NR & Intestine & NR & 66 \\
\hline "H heilmannii" * & Dogs, cats, monkeys, cheetahs, wild rats, swine & Stomach & NR & $1,9,95,96$ \\
\hline$H$ felis* & Dogs, cats, cheetahs & Stomach & NR & 2,118 \\
\hline
\end{tabular}

* Some data suggest zoonotic potential.

$N R$, not recorded.

misidentified (table 1). For example, it can not be distinguished from Campylobacter coli except by its lack of indoxyl acetate, and is indistinguishable from $C$ lari except for its lack of tolerance to $2 \% \mathrm{NaCl}$ and sensitivity to nalidixic acid. One report describes the use of fatty acid profiles to differentiate $H$ pullorum from C lari. ${ }^{22}$

Current identification of multiple species of microaerobic bacteria in faeces poses a particular challenge, especially when these microaerobes grow on similar media in comparable atmospheric conditions. Primary isolation of Campylobacter spp may be misleading because Helicobacter spp may be present in smaller numbers, and grow at a slower rate than Campylobacter spp. Their similar phenotypic traits and biochemical profiles also complicate a diagnosis. Accurate diagnosis of mixed infections with these bacteria may require diagnostic laboratories to incorporate polymerase chain reaction (PCR) based assays using Helicobacter and Campylobacter genus and species specific primers. This recommendation is supported by a recent study which reported improved sensitivity for PCR compared with conventional culture techniques in identifying
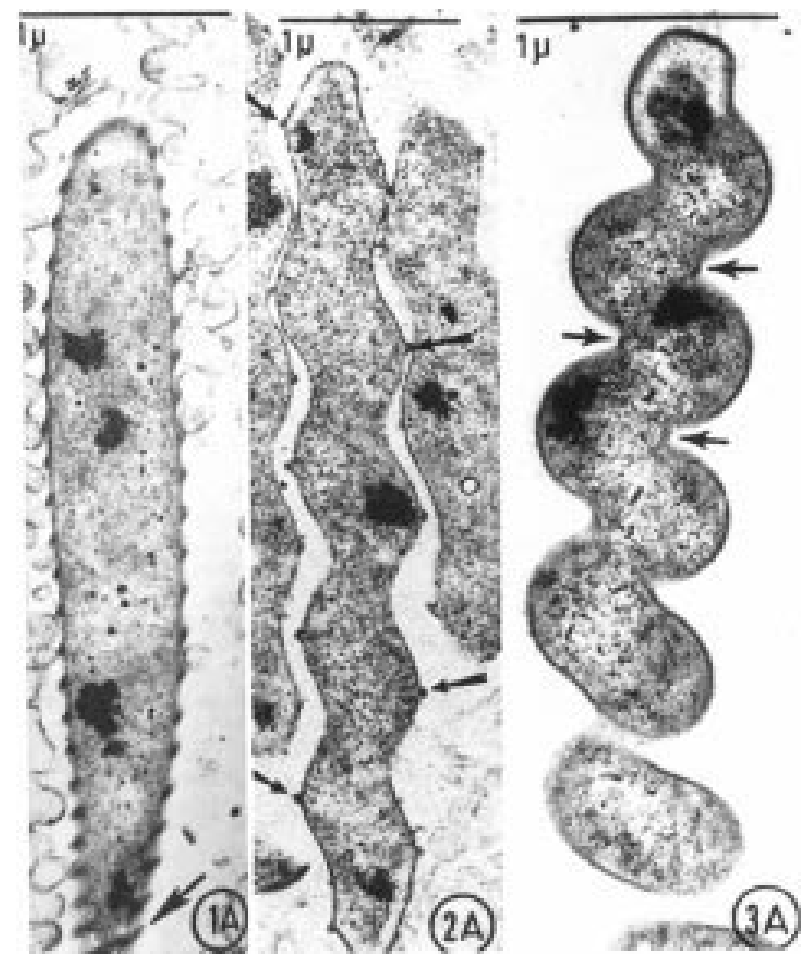

Figure 1 Collage of the original photomicrographs taken from Lockard and Boler ${ }^{9}$ of bacteria seen by electron microscopy in the dog stomach. Reprinted with permission of the American Journal of Veterinary Research. mixed infections of Campylobacter spp in human cases of gastroenteritis. ${ }^{23}$ Using genus specific Campylobacter and Helicobacter PCR assays should allow discrimination between the two species. ${ }^{24}$ Other authors have also strongly recommended that species specific PCR assays based on 16S rRNA genes be used for definitive diagnosis..$^{25} 26$

Investigators in South Africa have established a protocol to allow primary isolation of multiple species of Campylobacter and Helicobacter from individual diarrhoeic children. The technique uses selective filtration; the filtrates are placed onto antibiotic free blood agar plates, and incubated in an $\mathrm{H}_{2}$ enriched atmosphere. ${ }^{27} 28$

"Investigators in South Africa have established a protocol to allow primary isolation of multiple species of Campylobacter and Helicobacter from individual diarrhoeic children"

The authors not only documented an increase in the number of CLOs and helicobacter-like organisms (HLOs) isolated but they were able to culture $C$ upsaliensis for the first time. They also reported a $16.2 \%$ prevalence of multiple species of CLOs based on primary isolation, biochemical characterisation, and serological confirmation. The authors frequently recovered between two and five CLOs and HLOs from one stool sample,

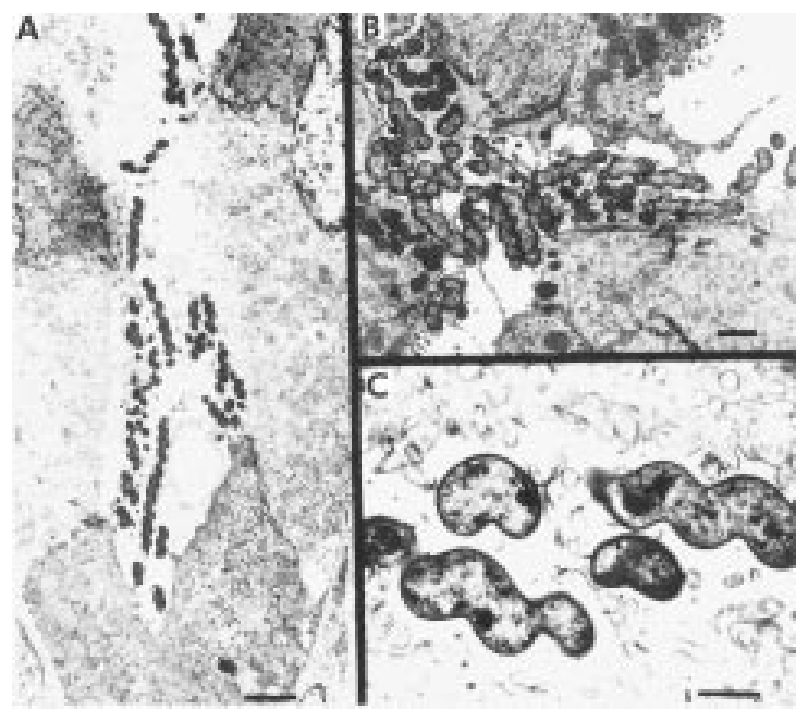

Figure 2 Transmission electron micrograph of gastric tissue from a cat showing large numbers of tight helix shaped bacteria resembling "Helicobacter heilmannii" in the gastric pits (A, B) and in close proximity to parietal cells $(C)$. Bars $=2,1$, and $0.5 \mu \mathrm{m}$ in $(A),(B)$, and (C), respectively. Reprinted from the Journal of Clinical Microbiology with permission from the author. ${ }^{95}$ 


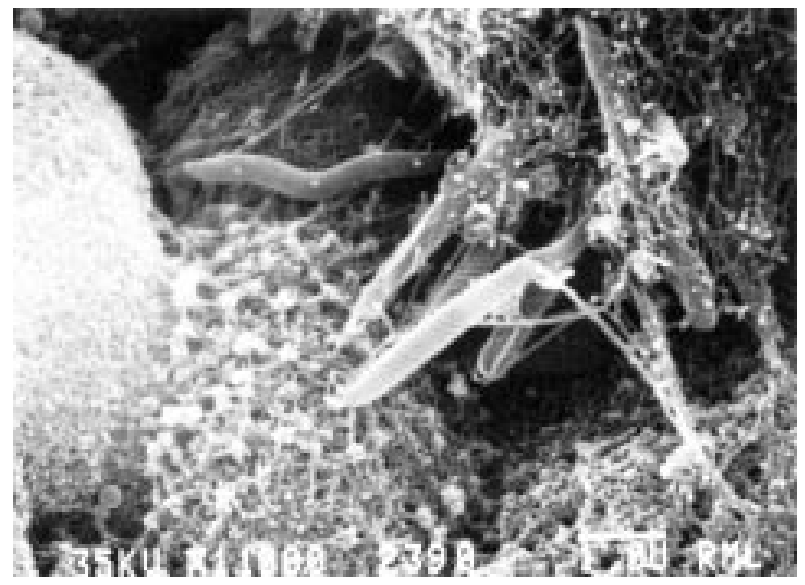

Figure 3 Scanning electron micrograph of "Helicobacter rappini" in the colon of a mouse. Also notice bacterium in the background with the morphology of $H$ hepatitis (courtesy of DB Schaver).

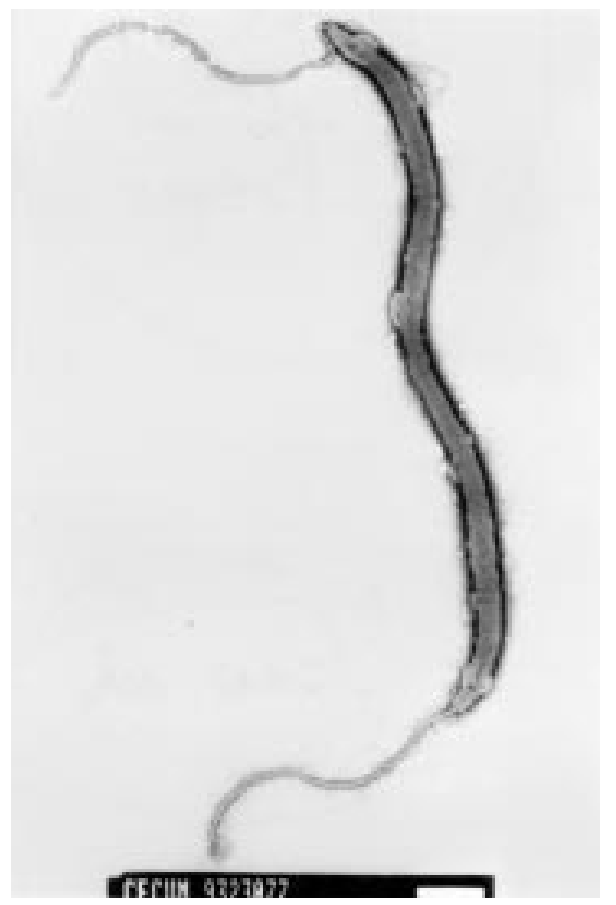

Figure 4 Negatively stained preparation of Helicobacter hepaticus isolated from the caecum of a mouse. Typical cell with a single subterminal flagellum at either end (bar $=500 \mathrm{~nm}$ ) (courtesy of the author).

with $C$ jejuni (with different serotypes), $C$ coli, $C$ upsaliensis, $H$ fennelliae, and $H$ cinaedi being commonly isolated. ${ }^{27}$ Mixed CLO and HLO infections were also recently reported in cats using PCR based methods. ${ }^{24}$

Direct PCR of faecal samples as well as other body fluids for diagnosis of enteric helicobacters has been hampered by the presence of inhibitory substances. To circumvent these difficulties, a screening technique for detecting Helicobacter spp in rodents was developed whereby reproducible PCR results are obtained following a simple and quick purification protocol. ${ }^{29}$ In this technique, bacteria are released from the faecal material by treatment with PVPP, an agent used to isolate bacteria from soil. The best results with the PVPP treated samples were obtained at $4^{\circ} \mathrm{C}$ with efficacy of the PCR reaction decreasing when the treatment was performed at higher temperatures, probably reflecting increased release of inhibitors at higher temperatures. As reported in other laboratories, addition of a Chelex 100 treatment enhanced the final PCR reaction. ${ }^{30}$ The use of a new commercially available QIAamp Tissue Kit (Qiagen, Inc., Chatsworth, California, USA) for DNA extraction from faecal samples has also proved extremely useful in detection of enteric helicobacters by PCR. ${ }^{32}$ Routine use of PCR techniques on human stool may prove useful as an adjunct for diagnosis for these fastidious microaerophiles. More recently, several enteric helicobacters have been assayed for cytolethal distending toxin (CDT). Its presence or absence as determined by PCR, cytopathic effect on cell cultures, and flow cytometry may assist in distinguishing among closely related species-for example, $H$ pullorum from $H$ canadensis. ${ }^{33-36}$

Gastric Helicobacter spp require special environmental and cultural conditions for their growth. The organisms are thermophilic, grow at $37^{\circ} \mathrm{C}$, and growth on chocolate or blood agar takes up to five days. The organisms do not grow under aerobic or anaerobic conditions and achieve optimum growth in a high humidity with microaerobic conditions $\left(5 \% \mathrm{CO}_{2}, 90 \%\right.$ $\mathrm{N}_{2}, 5 \% \mathrm{H}_{2}$ ). To date, however, isolation of these gastric helicobacters, $H$ felis and $H$ bizzozeronii (except for one isolate from a human), has been successful only in dogs and cats.

\section{HELICOBACTER ASSOCIATED DIARRHOEA $H$ cinaedi}

In 1984, a group of microaerobic CLOs were isolated from rectal swabs of male homosexuals suffering from protocolitis and enteritis. ${ }^{37}{ }^{38}$ These bacteria could be broadly classified into three major DNA homology groups. One of these was H cinaedi, previously classified as $C$ cinaedi (CLO-1A) (table 2). The second CLO2 was named C fennelliae, and the third still unnamed organism was classified as $\mathrm{CLO}^{39}{ }^{39}$ Although $H$ cinaedi has been primarily recovered from immunocompromised individuals, the organism has also been isolated from diarrhoeic faeces of chronic alcoholics, immunocompetent males and females, and children. ${ }^{40}{ }^{41}$ For example, Tee et al isolated nine strains of apparent enteric helicobacters from faecal cultures of over 1000 patients with gastroenteritis; three were classified biochemically and by DNA/DNA hybridisation as $H$ cinaedi. ${ }^{42}$

\begin{abstract}
"Although $\mathrm{H}$ cinaedi has been primarily recovered from immunocompromised individuals, the organism has also been isolated from diarrhoeic faeces of chronic alcoholics, immunocompetent males and females, and children"
\end{abstract}

In an attempt to understand the pathogenesis of $H$ cinaedi and $H$ fennelliae infection, pigtailed macaques (Macaca nemestrina) were experimentally challenged by the oral route with the organisms. ${ }^{43}$ Both $H$ cinaedi and $H$ fennelliae caused bacteraemia, diarrhoea, and focal colonic lesions. One of five monkeys infected with $H$ fennelliae also had acute proctitis and $H$ cinaedi induced lymphoid hyperplasia. ${ }^{43}$ We have recently isolated $H$ cinaedi from an inflamed colon, mesenteric lymph node, and liver of a rhesus monkey. ${ }^{44}$ This case highlights the ability of enteric helicobacters to translocate across the intestinal epithelia. Isolation of other novel helicobacters from inflamed colons of monkeys is also consistent with the increasing recognition of enteric helicobacters in children with gastroenteritis who reside in developing countries. ${ }^{27} 4546$

\section{Zoonotic potential}

Since $H$ cinaedi has been isolated from normal intestinal flora of hamsters, it has been suggested that pet hamsters serve as a reservoir for transmission to humans (table 2). ${ }^{20}{ }^{47}$ This fastidious microaerophile was recovered from blood of a neonate with septicaemia and meningitis. ${ }^{40}$ The mother of the neonate had cared for pet hamsters during the first two trimesters of 
her pregnancy. ${ }^{40}$ The mother had a diarrhoeal illness during the third trimester of pregnancy; the newborn was likely to have been infected during the birthing process although this was not proved. Further studies are needed to confirm the zoonotic risk of handling $H$ cinaedi infected hamsters. ${ }^{20}$ Also of interest is the isolation, based on cellular fatty acid and identification analysis, of $H$ cinaedi from the faeces of dogs and a cat. ${ }^{19}$ In a recent case of $H$ cinaedi associated arthritis, the patient occasionally worked with cows and farm animals. ${ }^{48} \mathrm{H}$ cinaedi was also recently isolated from the colon and liver of a rhesus monkey with colitis and hepatitis. ${ }^{44}$

\section{H fennelliae}

Like $H$ cinaedi, $H$ fennelliae, previously known as $C$ fennelliae, was first isolated from rectal swabs of homosexuals with chronic diarrhoea and proctitis. ${ }^{37}{ }^{38}$ However, unlike $H$ cinaedi, this enteric helicobacter does not often cause bacteraemia in adults. $^{49} 50$

\section{Zoonotic potential}

Although $H$ fennelliae has been identified in the faeces of a dog and macaque, no direct evidence of zoonotic transmission has been reported. ${ }^{19}$

\section{H canis}

A $H$ fennelliae-like organism was isolated from the faeces of a child suffering from gastroenteritis. ${ }^{51} \mathrm{H}$ canis has also been isolated from bacteraemic humans. ${ }^{39} 52$ The bacteria were distinguished from $\mathrm{H}$ fennelliae by their ability to grow at $42^{\circ} \mathrm{C}$, failure to produce catalase, and marked tolerance to bile. Morphologically, the bipolar sheathed flagella of $H$ canis are similar to those in $H$ cinaedi and $H$ fennelliae, and are useful in characterising the organism as a helicobacter.

\section{Zoonotic potential}

The same bacteria were isolated from faeces of normal and diarrhoeic dogs and were classified, based on 16S rRNA sequencing, as a novel helicobacter and named $H$ canis. ${ }^{53}$ It has been isolated from a colony of cats with endemic diarrhoea and from clinically normal cats. ${ }^{24}{ }^{54}$ Our laboratory has also identified $H$ canis based on 16S rRNA data from the liver of a puppy diagnosed as having an active multifocal hepatitis. ${ }^{52}$ Additional investigations will be required to ascertain whether $H$ canis in dogs and cats constitutes a potential reservoir for zoonotic transmission to humans. The fact that other microaerophilic bacteria-for example, Campylobacter jejuniare associated with zoonotic transmission to humans, especially children handling young puppies and kittens, strengthens the argument that dogs and cats may be responsible for zoonotic infection of helicobacters. ${ }^{53}$ It is also important to note that both helicobacters (including $H$ canis) and campylobacters can be isolated from diarrhoeic faeces of individual pet animals and humans; careful diagnostic efforts are therefore needed to properly identify mixed infections with these microaerobic bacteria. ${ }^{27} 54$

\section{"H rappini" (Flexispira rappini)}

Based on our recent 16S rRNA analysis of numerous " $H$ rappini" strains from multiple sources, these organisms are members of at least 10 species of closely related " $H$ rappini" taxa. "H rappini" was first reported in two humans with chronic diarrhoea and their pets. ${ }^{56}$ A novel Helicobacter $\mathrm{sp}$ isolated from cotton top tamarins with chronic diarrhoea also belongs to the $H$ rappini taxa. ${ }^{46}$ Bacteria of this morphology by electron microscopy have also been noted in rat enterocytes ${ }^{57}$ and more recently in the colon of normal mice, or enterocytes and lamina propria of mice experimentally infected with Serpulina dysenteriae. ${ }^{11} 58$
Zoonotic potential

Identical "H rappini" strains have been isolated from the faeces of both dogs and their owners, and the occurrence of $H$ rappini was associated with cellulitis following a cat scratch. The latter case may simply reflect the fact that the patient had $H$ rappini colonisation of his bowel and that the organism gained access to the blood via translocation. However, there is an apparent likelihood of zoonotic transmission with this organism. $^{565960}$

\section{$H$ pullorum}

Novel helicobacters, named H pullorum, isolated from caeca of normal chickens, the livers and intestinal contents of chickens with hepatitis, and faeces of humans with gastroenteritis have been characterised biochemically, by DNA hybridisation, and by $16 \mathrm{~S}$ rRNA sequencing. ${ }^{61}$ This bacterium is urease negative and can be distinguished from most other helicobacters by lack of sheathed flagella. Like $H$ hepaticus, $H$ canis, and $H$ bilis (all three capable of colonising the liver), H pullorum is tolerant to bile. The potential of H pullorum to cause serious gastrointestinal disease is evidenced by isolation of the organism from a young woman and a young man, both of whom suffered from chronic diarrhoea of one month's duration. ${ }^{62}$ The young man also had elevated liver enzymes, which although not proved, may have been induced by invasion of the liver by H pullorum in a manner similar to the organism's ability to cause hepatitis in chickens. Since then, $H$ pullorum associated gastroenteritis has been increasingly recognised in both Europe and North America. ${ }^{26} 63$

Cytotoxic activity in a member of the CDT family of bacterial toxins has been reported in a number of enterohepatic helicobacters, including $H$ pullorum. ${ }^{34}{ }^{36} \mathrm{CDT}$ activity is characterised by the appearance of cellular distension, cytoskeletal abnormalities, $\mathrm{G}_{2} / \mathrm{M}$ cell cycle arrest, and cytolethality in cultured cell lines treated with bacterial culture supernatants or sonicates of bacteria expressing the toxin. ${ }^{34}{ }^{36}$ Although the mode of action of enterohepatic helicobacter CDT on eukaryotic cells is unknown, it was recently shown that bacterial CDT induced cell cycle arrest in Escherichia coli, and $C$ jejuni was associated with a DNase activity intrinsic to the CDTB polypeptide. This toxin may play a role in the pathogenesis of enterohepatic disease by targeting lymphocytes and causing cell cycle arrest. ${ }^{6465}$

\section{Zoonotic potential}

$H$ pullorum is isolated from faeces and liver of chickens. Given that chickens are major zoonotic reservoirs of $C$ jejuni in humans, it is probable that chickens infected with $\mathrm{H}$ pullorum could also be responsible for infection in humans. ${ }^{61}$ Also, because of the difficulty of differentiating campylobacters from helicobacters by routine biochemistry tests, campylobacter related infections due to eating undercooked poultry may indeed on occasion be misdiagnosed.

\section{"It is probable that chickens infected with $H$ pullorum could also be responsible for infection in humans"}

Further molecular characterisation may indicate that the isolates were H pullorum. This needs to be confirmed in additional studies.

\section{$H$ canadensis}

Numerous helicobacter isolates cultured from diarrhoeic patients in Canada were recently analysed. ${ }^{26}$ These bacteria had been previously characterised biochemically, by restriction fragment length polymorphism (RFLP) (AluI, HhaI), and by fatty acid analysis as $H$ pullorum. However, four of the isolates varied biochemically from $\mathrm{H}$ pullorum by their inability to hydrolyse indoxyl acetate and their resistance to nalidixic acid. Using complete 16S rRNA analysis we determined that 
these four strains clustered near $H$ pullorum but had a sequence difference of greater than $2 \%$ and therefore represent a novel helicobacter, $H$ canadensis. ${ }^{33}$ This novel helicobacter could also be distinguished from $H$ pullorum by RFLP using ApaLI and the lack of CDT. ${ }^{33}$ This finding highlights the importance of careful molecular analysis in addition to standard biochemical tests in speciating the increasing number of Helicobacter spp isolated from humans and animals.

\section{H winghamensis}

From 1997 to 1999, five isolates of CLOs were identified from three Canadian patients that were exhibiting symptoms of gastroenteritis, including fever, stomach malaise, and diarrhoea. The organisms were catalase, urease, alkaline phosphatase, and nitrate negative but oxidase and indoxyl acetate positive. Complete 16S rRNA sequence analysis grouped these organisms within the Helicobacter genus and also differentiated them from previously identified Helicobacter spp. The closest relative by phylogenetic analysis was "H rappini", taxon 1 . Electron microscopy illustrated that these isolates had 1-2 bipolar flagella; however, the periplasmic fibres characteristic of $H$ rappini were not observed. The isolates also lacked a flagellar sheath, a trait shared with four other helicobacters, $H$ canadensis, $H$ pullorum, $H$ rodentium, and $H$ mesocricatorum. ${ }^{66}$

\section{HELICOBACTER ASSOCIATED BACTERAEMIA, CELLULITIS, AND ARTHRITIS

$H$ cinaedi has been isolated from the blood (sometimes on a recurrent basis) of homosexual patients with human immunodeficiency virus (HIV) as well as children and adult females. ${ }^{40414967-72}$ It is also interesting to note that $H$ cinaedi can cause bacteraemia in immunocompetent adults and children with and without diarrhoea. ${ }^{41}$

"H cinaedi has been isolated from the blood (sometimes on a recurrent basis) of homosexual patients with human immunodeficiency virus (HIV) as well as children and adult females"

$\mathrm{H}$ cinaedi was also isolated from the blood of experimentally infected macaques receiving an oral inoculum of $H$ cinaedi. ${ }^{43} \mathrm{In}$ a retrospective study of 23 patients with $H$ cinaedi associated illness, 22 had the organism isolated from blood using an automated blood culture system where a slightly elevated growth index was noted. ${ }^{18}$ This study also described a new $H$ cinaedi associated syndrome, consisting of bacteraemia and fever accompanied by leucocytosis and thrombocytopenia. Recurrent cellulitis and/or arthritis are also noted in a high percentage of $H$ cinaedi infected immunocompromised patients. ${ }^{1873}$

In the study by Burman et al, four of seven patients with bacteraemia had a variety of skin lesions, including cellulitis, erythema nodosum, and erythematous plaques. ${ }^{73}$ In contrast, others noted that in $H$ cinaedi bacteraemic cases, cellulitis may be atypical; in 9/23 cases the cellulitis was characterised as brown or copper coloured skin without the associated heat typical of inflammation. ${ }^{18}$ In isolated cases, cellulitis can develop into lymphoedema. ${ }^{72}$

Antimicrobial in vitro testing of 22 strains of $H$ cinaedi provide the clinician with a variety of antibiotics to use in treating infected patients. ${ }^{74}$ Tetracycline and various aminoglycosides appear to be effective in treating infections with $H$ cinaedi. Apparent relapses of $H$ cinaedi bacteraemia in patients treated with ciprofloxicin (despite its previous use to successfully treat $H$ cinaed infection) and the occurrence of in vitro resistance of $H$ cinaedi isolates to ciprofloxicin, suggest that this antibiotic should be used with caution. ${ }^{18} 197475$

\section{"H westmeadii"}

In 1997, a novel helicobacter, $H$ westmeadii, was cultured from the blood of two HIV infected patients. ${ }^{76}$ "H westmeadii", although morphologically and biochemically similar to $H$ cinaedi, was previously distinguished by its ability to hydrolyse hippurate and grow anaerobically. Also, the authors stated that results of ribotyping, fatty acid analysis, and 16S rRNA ribosomal sequences made it distinctly different from $H$ cinaed $i$ and $H$ fennelliae. By electron microscopy, there is little morphological difference between $H$ cinaedi, $H$ fennelliae, and $H$ westmeadii, all having single sheathed polar flagella. $H$ cinaedi and $H$ fennelliae are longer $(2.5-5 \mu \mathrm{m})$ and thicker $(0.5-1 \mu \mathrm{m})$ than $H$ westmeadii which are $1.5-2 \mu \mathrm{m} \times 0.5 \mu \mathrm{m}$ in diameter. Vandamme et al raises the question of whether $H$ westmeadi is a separate species or a junior synonym of $H$ cinaedi. They based their results on numerical analysis of whole cell protein electrophoresis, extensive biochemical analysis, and semiquantitative DNA-DNA hybridisation experiments. ${ }^{77}$

One HIV infected individual who had " $H$ westmeadi" bacteraemia was admitted because of pyrexia and neutropenia following chemotherapy. His medications on admission consisted of dapsone (100 mg daily), fluconazole (400 mg daily), and acyclovir (200 mg twice daily). After recovery of a Gram negative rod from his blood, he was treated empirically with tricarcillin-clauvlamate and tobramycin. His fever subsided and his leucocyte count became elevated. However, he died 11 months later with advanced Kaposi's sarcoma. In the second bacteraemic patient, there was a previous history of being HIV positive and having related diseases, including oral candidiasis, diarrhoea, and weight loss. He was subsequently admitted with a four week history of cellulitis in the right leg. He had " $H$ westmeadi" isolated from a blood culture and was treated with penicillin and flucloxacillin without clinical improvement. He developed a maculopapular rash and oral candidiasis; his treatment was changed to cephalothin, to which he initially responded. He later developed recurrent lesions on both legs which resolved with time; however, the patient died several months later of HIV related illness. ${ }^{76}$

\section{H fennelliae}

$H$ fennelliae has been isolated from a bacteraemic child with leukaemia $^{78}$ and was responsible for septic shock in a non HIV-infected heterosexual patient. ${ }^{79}$ However, this patient was undoubtedly immunocompromised because of liver cirrhosis and diabetes mellitus, as well as pre-existing disseminated fungal infections. One HIV seropositive patient, suffering from successive bacteraemia, had both $H$ cinaedi and $H$ fennelliae isolated from his blood at different times. ${ }^{49}$ These patients also have diarrhoea concurrent with the isolation of $H$ fennelliae from their blood.

Non-standardised in vitro testing suggest that $H$ fennelliae is susceptible to a variety of antibiotics including ciprofloxacin, doxycycline, gentamicin, rifampin, and sulphamethoxazole. ${ }^{74}$ Intravenous chloramphenicol has also been used to treat bacteraemic patients. ${ }^{49}$

\section{"Non-standardised in vitro testing suggests that $H$ fennelliae is susceptible to a variety of antibiotics"}

One patient with $H$ fennelliae bacteraemia responded clinically to intravenous ampicillin-sulbactam and ceftazidine followed by ampicillin-sulbactam. The patient remained well at follow up, six months after being discharged from hospital. ${ }^{79}$

\section{H rappini}

Isolation of $H$ rappini from the blood of experimentally infected guinea pigs 1.5 weeks after inoculation indicates the ability of these organisms to cause bacteraemia. ${ }^{10}$ Also, the observation of translocation of $H$ rappini-like organisms in enterocytes of cotton top tamarins with ulcerative colitis or 
mice coinfected with Serpulena hyodysentereae supports this viewpoint. ${ }^{158}$ Helicobacter rappini-like organisms were recently isolated from a nine year old bacteraemic child with pneumonia. ${ }^{80}$ The organism was grown in a paediatric bottle (BACT/Alert Microbial detection system Organon Technika). The child was successfully treated with erythromycin. Also, " $H$ rappini" was isolated on two occasions from the blood of an HIV negative 65 year old febrile patient undergoing haemodialysis for end stage renal disease.$^{60} \mathrm{He}$ had a history of chronic pancreatitis due to alcoholism and also had secondary diabetes which required insulin therapy. Two months prior to the septic episode with "H rappini", the patient had suffered from cellulitis, secondary to a cat scratch.

\section{"Helicobacter rappini-like organisms were recently isolated from a nine year old bacteraemic child with pneumonia"}

The strains were recovered from aerobic blood culture media (Bactec Plus Aerobic/F) but not from anaerobic culture media (Bactec Anaerobic/F). By whole protein numerical analysis and biochemical characteristics, the organism was indistinguishable from the LMG 8738 strain (ATCC 43879) first described by Archer and colleagues. ${ }^{56}$ "H rappini" from this patient was $>99 \%$ similar by $16 \mathrm{~S}$ rRNA analysis to that of " $H$ rappini" strain ATCC 43966. ${ }^{60}$ The "H rappini" recovered from the patient with end stage renal disease and alcoholism appeared by in vitro criteria (using inhibition zones of $>30$ $\mathrm{mm}$ around antibiotic discs) to be more sensitive to antibiotics than the Archer strain..$^{56}$ The strain was susceptible to ceftriaxone, meropenem, erythromycin, clindamycin, clarithromycin, doxycycline, gentamicin, amikacin, ciprofloxacin, nitrofurantoin, and metronidazole. This "H rappini" strain was considered to be resistant to penicillin $\mathrm{G}$ and cefazolin because no zone of growth inhibition was observed. Susceptibility to ampicillin and co-trimoxazole appeared to be decreased (inhibition zone diameters of 28 and $22 \mathrm{~mm}$, respectively). ${ }^{60}$ These results were consistent with the clinical failure in this patient when treated with co-trimoxazole and clinical cure when treated with meropenem.

Recurrent $H$ rappini associated bacteraemia over a period of several months, despite several courses of antibiotics, has also been noted in two patients with prolonged cellulitis and $\mathrm{X}$ linked agammaglobulinaemia (XLA) ${ }^{81}{ }^{82}$ Both of the $H$ rappini-like organisms in the XLA patients, by DNA-DNA hybridisations, were $81 \%$ related to each other but only $<70 \%$ to "H rappini" (ATCC strain 43966). In both patients the organism was grown in aerobic paediatric BacTAlert (Organon Teknika Corp, Durham, North Carolina, USA) blood culture media. It was then successfully subcultured using microaerobic conditions that included $\mathrm{H}_{2}$. The use of phase contrast microscopy of blood culture to observe the characteristic darting motility as well as acridine orange staining of these bacteria proved very helpful for selecting conditions for incubation of subcultures. ${ }^{81} 82$

\section{"Recurrent $H$ rappini associated bacteraemia over a period of several months, despite several courses of antibiotics, has also been noted in two patients with prolonged cellulitis and $X$ linked agamma- globulinaemia"}

The first XLA patient was 36 years old when he had " $\mathrm{H}$ rappini" isolated from his blood on multiple occasions. He had XLA diagnosed at age four years and was treated with intramuscular gamma globulin until age 32 years. At age 34 years he developed leg swelling, fever, night sweats, and anorexia. The "cold" cellulitis progressed to a woody appearing skin lesion suggestive of lymphatic obstruction. In this case, in vitro antibiotic testing using E test strips indicated that " $H$ rappini" were resistant to ampicillin, azithromycin, ceftriaxone, chloramphenicol, ciprofloxacin, and clindamycin ${ }^{82}$ The organism was sensitive to imipenem, metronidazole, minocycline, and rifampin and showed intermediate sensitivity to doxycycline. Based on these findings, the patient was initially treated with doxycycline and metronidazole with noted clinical improvement of the cellulitis. Blood cultures remained positive however, and treatment was changed to oral amoxcillin-clavulanic acid, minocycline, and rifampin. ${ }^{82}$ Initial improvement was again noted but recurrence of symptoms followed. Intravenous gentamicin and imipenem were then initiated and continued for five months which achieved resolution of systemic infection and negative follow up on blood cultures. ${ }^{82}$ In the second case of XLA, the patient had a history of this disease since he was six months old. He had been diagnosed as having pyoderma granulosum with non-healing skin ulcers and swelling of the leg at age 17 years. At age 18 years, he developed pyrexia and was treated with intravenous gentamicin, metronidazole, and vancomycin. The fever resolved and the skin ulcers healed, but after treatment was terminated the lesions recurred. At age 21 years, with no improvement in clinical signs, blood samples were taken and "H rappini"-like organisms were cultured on several occasions. The patient was also determined to have osteomyelitis by magnetic resonance imaging. Surgical bone debridement of the femur, tibia, and calcaneous of the opposite leg was performed; culture of these sites also grew "H rappini"-like organisms. Treatment with intravenous imipenem and gentamicin led to initial resolution of the fever and macular rash with gradual improvement in the ulcers. Gentamicin was discontinued (because of hearing loss) and replaced by intravenous meropenum. After nine months of intravenous antibiotics, the ulcers substantially improved and therapy was stopped. These two cases of XLA highlight the apparent susceptibility to $H$ rappini-like infections due to a $\mathrm{B}$ cell (humoral) immunodeficiency with resultant intravascular and intralymphatic infections.

\section{ENTEROHEPATIC HELICOBACTERS: DO THEY CAUSE HEPATOBILIARY DISEASE IN HUMANS?}

Several Helicobacter spp colonise the livers of animals and induce hepatitis. ${ }^{34174452}$ As a result, several recent studies have been undertaken to determine whether Helicobacter spp are associated with cholecystitis and other hepatobiliary diseases in humans. Cancer of the gall bladder is the number one cause of cancer mortality in Chilean women. The incidence of this gall bladder tumour vary widely on a worldwide basis, being approximately 30 times higher in high risk than in low risk populations, suggesting that environmental factors such as infectious microorganisms, carcinogens, and nutrition play a role in its pathogenesis and in some cases liver tumours.

\section{"Several recent studies have been undertaken to determine whether Helicobacter spp are associated with cholecystitis and other hepatobiliary diseases in humans"}

In one study, bile or resected gall bladder tissue from 46 Chileans with chronic cholecystitis undergoing cholecystectomy were cultured for Helicobacter spp and subjected to PCR analysis using Helicobacter specific $16 \mathrm{~S}$ ribosomal RNA primers. ${ }^{83}$ Recovery of Helicobacter spp from frozen specimens was unsuccessful. However, by PCR analysis, 13/23 bile samples and 9/23 gall bladder tissues were positive for Helicobacter spp. Eight of the Helicobacter specific PCR amplicons were sequenced and subjected to phylogenetic analysis. Five sequences represented strains of $H$ bilis, two strains of " $H$ rappini" (ATCC 49317), and one strain of H pullorum. These data 
support an association of bile resistant Helicobacter spp with gall bladder disease. ${ }^{83}$

Subsequently, Rudi and colleagues ${ }^{84}$ showed that Helicobacter spp were not detected by PCR in bile from German patients with biliary diseases. Germany has a low incidence of bile duct and gall bladder cancer, and so they assumed that the discrepancy between their results and those of Fox and colleagues $^{83}$ could be explained by regional differences in the distribution of bile resistant Helicobacter species.

Primary sclerosing cholangitis (PSC) is another chronic cholestatic liver disease of unknown aetiology. Pathological lesions consist of persistent inflammation with destruction and fibrosis of intrahepatic and extrahepatic bile ducts. The high correlation of PSC and ulcerative colitis has raised the hypothesis that chronic portal bacteraemia may initiate inflammation and promote subsequent hepatobiliary damage. A study was therefore undertaken to ascertain whether Helicobacter spp known to cause hepatobiliary disease in animals were present in PSC patients. ${ }^{85}$ Liver biopsies and bile were obtained from eight patients with PSC. Trypticase soy agar with 5\% sheep blood, TVP, and CVA medium were used for Helicobacter spp isolation. The primers chosen for PCR amplification recognised conserved regions of the 16S rRNA specific for all known Helicobacter spp and produced an amplified product of $1220 \mathrm{bp}$. For confirmation of the PCR amplified fragment, Southern blot hybridisation was performed with a Helicobacter specific PCR generated probe. Although Helicobacter spp were not cultured, they were identified by PCR amplification and Southern hybridisation using a Helicobacter specific probe in five of eight patients. ${ }^{85}$ In three of these patients, a 1200 bp PCR amplified product was successfully cloned and sequenced. Analysis of the sequences indicated high homology to the $16 \mathrm{~S}$ rRNA sequences of a cluster of Helicobacter spp previously isolated from animals-that is, $H$ rodentium, $H$ rappini, and $\mathrm{H}$ pullorum. ${ }^{85}$

"The difficulty in obtaining gall bladder and liver tissues from selected populations highlights the need for non-invasive serological assays to determine the prevalence of hepatic Helicobacter organisms in various biliary and hepatic diseases of humans"

Nilsson et al have recently found Helicobacter spp (including $H$ pylori) using Helicobacter spp specific PCR in the livers of PSC patients as well as in patients with primary biliary cirrhosis, another idiopathic biliary disease ${ }^{86}$ Bile and liver samples were PCR positive for Helicobacter DNA in nearly half of 24 patients with primary biliary cirrhosis and PSC. Interestingly, Helicobacter spp were not identified in control patient livers or in patients with non-cholestatic liver disease. The difficulty in obtaining gall bladder and liver tissues from selected populations highlights the need for non-invasive serological assays to determine the prevalence of hepatic Helicobacter organisms in various biliary and hepatic diseases of humans. Nilsson et al also reported an immunoblot assay to discriminate between $H$ pylori, $H$ hepaticus, and $H$ bilis infections in humans. Cross reacting antibodies as well as $H$ hepaticus specific antibodies were detected in serum samples from patients with various liver diseases. ${ }^{87}$ These authors concluded that sera IgG antibodies to $H$ hepaticus were present in 56 of 144 (39\%) patients with chronic liver diseases, including six of 30 patients with PSC. ${ }^{87}$ However, sera antibody to $H$ hepaticus in diseased patients was not increased compared with healthy blood donors. They also noted that seroconversion to $H$ pylori was frequently noted but there was no clear association of $H$ pylori seroreactivity to a specific disease category. A study of Mexican patients with gall stone disease found only a low prevalence of helicobacters in gall bladder epithelium by immunohistochemistry (1/95) and PCR (1/32). ${ }^{88}$

In France, investigators cited the presence of Helicobacter spp DNA in liver tissue in eight of eight patients with primary liver carcinoma whereas Helicobacter DNA was found in only one control case $(1 / 8)$ without liver disease ${ }^{89}$ Others in Sweden have identified Helicobacter spp DNA in liver cancer cases. ${ }^{90}$

Since bile acids, intestinal acids, and highly charged mucin components are strong inhibitors of the PCR reaction, all of these studies have to be interpreted with caution until methods to safely remove or neutralise the effect of these inhibitors in bile, bile tract, and liver biopsies have been developed. To date, none of these studies have been able to culture Helicobacter from bile or liver. Further studies using specific and sensitive detection methods are needed to ascertain the association of Helicobacter infection with hepatobiliary diseases in different populations.

\section{NON-H PYLORI GASTRIC HELICOBACTERS ISOLATED FROM HUMANS "H heilmannii" (Gastrospirillum hominis)}

Of the known gastric Helicobacter spp, "H heilmannii" has the largest number of known mammalian hosts. These gastric HLOs have commonly been observed microscopically in the stomachs of dogs, cats, cheetahs, swine, wild rats, various species of non-human primates, and in a small percentage of humans with gastritis. ${ }^{1291-96}$ Characterisation of these bacteria has relied on 16S rRNA analysis because of the inability to grow the organisms on artificial media. Maintenance of bacteria in the laboratory, other than in a frozen state, has relied on preparation of these gastric spirals in the stomachs of mice. ${ }^{8}$ Recently however, investigators from Finland have been able to culture a large spiral bacteria from gastric biopsies of dogs. ${ }^{14}$ They have named the organism $H$ bizzozeronii in honour of the Italian pathologist who was one of the first scientists credited with the observation of these organisms in the stomach of mammals. ${ }^{14}$ For in vitro growth, the organism required a fresh moist medium containing antibiotics, a microaerobic environment, and a 5-10 day incubation period. ${ }^{1497}$ A case report of isolation of a $H$ heilmannii-like organism was also reported in a human with gastritis. ${ }^{98}$ This isolate was susceptible to amoxicillin, metronidazole, and tetracycline.

A diagnosis of humans infected with $H$ heilmannii, first observed and reported in three humans in 1987, has been made on morphological grounds by a variety of authors assessing human gastric biopsies. ${ }^{13}{ }^{13}{ }_{99-102}$ The frequency of occurrence is between $0.25 \%$ and $0.60 \%$ depending on the study. However, as many as $6 \%$ of patients in Thailand and China have been reported to be infected with " $H$ heilmannii". ${ }^{103} 104$

\section{"H heilmannii is located in the deep part of the gastric pits of human patients whereas $H$ pylori colonises more frequently the mucus layer of surface epithelia"}

Heilmann and Borchard ${ }^{1}$ examined 15180 gastric biopsies and observed the gastric helicobacter in 39 German patients, 34 of whom had a chronic active gastritis, and the remaining five had a chronic gastritis consisting of a lymphoplasmacytic inflammation. $H$ heilmannii is located in the deep part of the gastric pits of human patients whereas $H$ pylori colonises more frequently the mucus layer of surface epithelia. The gastric HLOs can also invade parietal cells in a manner similar to gastric HLO in other mammals. Pathologists have also systematically compared the histology of "H heilmannii" and $H$ pylori in a large group of patients. ${ }^{105}$ A total of 202 patients with " $H$ heilmannii" infection were compared with an equal number of $H$ pylori infected individuals. "H heilmannii" associated gastritis was more mild compared with $H$ pylori gastritis cases. ${ }^{105}$ In the Heilmann study, 34 of the 39 patients complained of upper abdominal discomfort. Other reports indicate that patients infected with gastric HLOs can have intermittent epigastric pain, and occasional bleeding is noted from peptic 
ulcers. ${ }^{102}{ }^{106-111}$ These helicobacters can persist in humans for years, and presumably the same is true for other mammals.

"H heilmannii" has also been associated with primary gastric low grade lymphoma in humans. ${ }^{100} 112$ Similar to $H$ pylori associated lymphoma, clinical remission of the lymphoma was noted in five patients after antibiotic eradication of the gastric helicobacter. ${ }^{100113114}$

\section{"H heilmannii has also been associated with primary gastric low grade lymphoma in humans"}

Eradication of " $H$ heilmannii" by antimicrobial therapy has also resulted in the resolution of gastritis and peptic ulcer disease. ${ }^{19} 115$ "H heilmannii" infections have been successfully treated with bismuth alone and with combination therapies that included metronidazole or amoxicillin. ${ }^{1} 989$

\section{Zoonotic potential}

Because "H heilmannii" ("H bizzozeronii") and to a lesser extent $H$ felis colonise a small percentage of humans with gastritis, and no environmental source for these bacteria has been recognised, pets have been implicated in zoonotic transmission of the organisms. Using a questionnaire, 125 German patients infected with gastric HLOs provided information regarding animal contact. Of these, $70.3 \%$ had contact with one or more animals (compared with $37 \%$ in the "normal" population). More than a threefold preponderance of male over female patients with gastric HLOs was recorded. ${ }^{91}$ In addition to dogs and cats as potential zoonotic hosts of these gastric helicobacters, swine may also be a source of infection to humans. ${ }^{116}$

In one report of "H heilmannii" infection, the household had two cats; a gastric biopsy from one cat indicated it was infected with gastric spiral organisms with similar morphology to that depicted in the child's stomach. ${ }^{101}$ In another report, a pet cat and its owner had "H heilmannii" identified in their gastric mucosa. The authors noted that each of the $H$ heilmannni strains had a $580 \mathrm{bp}$ region of the ureB gene that were identical. ${ }^{117}$

Another study closely links the occurrence of gastric HLOs infection with exposure to companion animals. ${ }^{101} \mathrm{~A} 12$ year old girl after moving to a farm (with various domestic animals, including dogs), developed an 18 month history of epigastric pain, nausea, vomiting, and anorexia. Treatment with $\mathrm{H}_{2}$ blockers did not relieve symptoms in the girl. An antral lymphonodular hyperplasia was noted at endoscopy and histologically an active chronic gastritis associated with " $H$ heilmannii" was present in the gastric biopsy. ${ }^{101}$ Institution of various anti-Helicobacter antimicrobial treatment-for example, amoxicillin and omeprazole for six weeks and metronidazole for 12 weeks-resulted in clinical improvement, but the symptoms in the girl returned shortly after treatment was ceased. This history suggested reinfection, and her two dogs (one asymptomatic, the other with a long history of vomiting) were endoscoped. The symptomatic dog which frequently licked the face of the girl had an active chronic gastritis associated with large numbers of " $H$ heilmannii". The asymptomatic dog also had a mild gastritis associated with fewer " $H$ heilmannii". The girl and the two dogs were simultaneously placed on a six week course of amoxicillin and bismuth. The symptoms in the dog resolved and endoscopy showed resolution of the gastritis. The girl's symptoms increased while on therapy and omeprazole (60 mg/day) was given. The girl remained symptom free three months after therapy. This case study suggests that the dog was the source of infection but without DNA fingerprinting of the " $H$ heilmannii" strains to confirm identity, the causal association is only suggestive. Nevertheless, eradication of the gastritis in the dogs apparently prevented subsequent relapse in the girl. ${ }^{101}$

\section{$\boldsymbol{H}$ felis}

Lee et al isolated a tightly coiled spiral organism from the gastric mucosa of cats in 1988. ${ }^{2}$ The bacterium had tufts of bipolar sheathed flagella and a body entwined with periplasmic fibres, which usually occurred in pairs. ${ }^{2}$ The bacteria were urease, catalase, and oxidase positive, typical biochemical features of other gastric helicobacters. In subsequent studies using 16S rRNA sequencing analysis and further biochemical characterisation, the organism was named $H$ felis. ${ }^{12}$ Gastric spiral bacteria with similar morphology (based on electron microscopy) have also been identified in the stomachs of dogs, cheetahs, swine, non-human primates, and wild rats. ${ }^{92}$ The organism is infrequently observed in human gastric biopsies in the gastric tissue of humans. ${ }^{118}$ Interestingly, BALB/c mice infected with $H$ felis develop a lymphoma-like gastric lesion which if treated with antimicrobials reduces the development of these gastric lesions. ${ }^{119}$ Also, the recent observation that $H$ felis infection in INS/GAS transgenic C57/BL mice induces gastric cancer adds credence to isolated case reports of "H heilmannii" associated gastric carcinoma. ${ }^{120-122}$ Coinfection with $H$ felis and " $H$ heilmannii" is often observed in animals and perhaps in humans as well. Indeed, it is impossible to distinguish the two organisms histologically by light microscopy.

\section{Zoonotic potential}

In one case study, a researcher performing physiological studies with cat stomachs developed an acute gastritis, presumably caused by $H$ felis based on electron microscopy. ${ }^{118}$ Similar gastric spiral bacteria were shown in gastric mucosa of cats being used by this scientist. The gastritis observed in $H$ felis infected dogs and cats is similar to that observed with "H heilmannii".

\section{CONCLUSION}

Over the past 20 years, the genus Helicobacter has evolved rapidly due to isolation of novel species from a wide range of animals and humans. The genus now includes at least 24 formally named species as well as numerous other helicobacters not formally named. Nineteen of these formally named helicobacters are found in the intestinal mucus of animals, eight in humans, and two in birds.

\section{"Infection with Helicobacter spp and their associated diseases in numerous hosts allow us the means to assess pathogenic mechanisms"}

Many of these helicobacters can also colonise the biliary tract of the liver and induce hepatitis (and in some cases hepatic cancer) or cause bacteraemia and systemic disease in immunocompromised hosts. ${ }^{3} 17123124$ Discovery of these helicobacters provides the scientific community with an excellent opportunity to study and better understand the finely balanced ecological relationship between these bacteria which persistently colonise the gastrointestinal tract and their effect on the host.

Infection with Helicobacter spp and their associated diseases in numerous hosts allow us the means to assess pathogenic mechanisms. In vivo models are also being used to develop various therapeutic and prophylactic modalities to eradicate or prevent helicobacter induced gastrointestinal disease in humans. In addition, it is important to study the epidemiology of helicobacters and their zoonotic potential as well as to identify novel Helicobacter spp and their possible associations with what are currently poorly defined disease syndromes.

\section{REFERENCES}

1 Heilmann KL, Borchard F. Gastritis due to spiral shaped bacteria other than Helicobacter pylori: Clinical, histological, and ultrastructural findings. Gut 1991;32:137-40.

2 Lee A, Hazell SL, O'Rourke J. Isolation of a spiral-shaped bacterium from the cat stomach. Infect Immun 1988;56:2843-50. 
3 Fox JG, Li X, Yan L, et al. Chronic proliferative hepatitis in $\mathrm{A} / \mathrm{JCr}$ mice associated with persistent Helicobacter hepaticus infection: a model of helicobacter-induced carcinogenesis. Infect Immun 1996;64: 1548-58.

4 Fox JG, Yan LL, Dewhirst FE, et al. Helicobacter bilis sp. nov., a novel Helicobacter isolated from bile, livers, and intestines of aged, inbred mice. J Clin Microbiol 1995;33:445-54

5 Solnick JV, Schaver DB. Emergence of diverse Helicobacter species in the pathogenesis of gastric and enterohepatic diseases. Clin Microbiol $\operatorname{Rev} 2001 ; 14: 59-97$

6 Shomer N, Dangler CA, Schrenzel MD, et al. Cholangiohepatitis and inflammatory bowel diease (IBD) induced by a novel urease-negative Helicobacter species in $\mathrm{A} / \mathrm{J}$ and Tac:ICR:Hascid mice. Biol Exp Med 2001;226:420-8.

7 Erdman SE, Fox JG, Dangler CA, et al. Typhlocolitis in NF-kB deficient mice. J Immunol 2001;66:1443-7.

8 Salomon H. Über das Spirillum des Säugetiermagens und sein Verhalten zu den Belegzellen. Zentralb/ Baketeriol [B] 1898:119:422-41.

9 Lockard VG, Boler RK. Ultrastructure of a spiraled microorganism in the gastric mucosa of dogs. Am J Vet Res 1970;31:1453-62.

10 Bryner JH, Ritchie AE, Pollet L, et al. Experimental infection and abortion of pregnant guinea pigs with a unique spirillum-like bacterium isolated from aborted ovine fetuses. Am J Vet Res 1987:48:91-7.

11 Schaver DB, Ghori N, Falkow S. Isolation and characterization of "Flexispira rappini" from laboratory mice. J Clin Microbiol 1993;31:2709-14

12 Paster BJ, Lee A, Fox JG, et al. Phylogeny of Helicobacter felis sp. nov. Helicobacter mustelae, and related bacteria. Int J Syst Bacterio 1991;41:31-8.

13 Solnick JV, O'Rourke J, Lee A, et al. An uncultured gastric spiral organism is a newly identified Helicobacter in humans. J Infect Dis 1993; 168:379-85.

14 Hanninen ML, Happonen I, Saari S, et al. Culture and characteristics of Helicobacter bizzozeronii, a new canine gastric Helicobacter sp. Int J Syst Bacteriol 1996;46:160-6.

15 Chalifoux LV, Brieland JK, King NW. Evolution and natural history of colonic disease in cotton-top tamarins (Saguinus oedipus). Dig Dis Sci 1985; $30: 54 S-8 S$.

16 Croucher SC, Houston AP, Bayliss CE, et al. Bacterial populations associated with different regions of the human colon wall. Appl Environ Microbiol 1983;45:1025-33.

17 Fox JG, Dewhirst FE, Tully JG, et al. Helicobacter hepaticus sp. nov, a microaerophilic bacterium isolated from livers and intestinal mucosal scrapings from mice. J Clin Microbiol 1994;32:1238-45.

18 Kiehlbauch JA, Tauxe RV, Baker CN, et al. Helicobacter cinaedi-associated bacteremia and cellulitis in immunocompromised patients. Ann Intern Med 1994;121:90-3.

19 Kiehlbauch JA, Brenner DJ, Cameron DN, et al. Genotypic and phenotypic characterization of $H$ cinaedi and $H$ fennelliae strains isolated from humans and animals. J Clin Microbiol 1995;22:2940-7.

20 Gebhart CJ, Fennell CL, Murtaugh MP, et al. Campylobacter cinaedi is normal intestinal flora in hamsters. I Clin Microbiol 1989:27:1692-4.

21 Atabay I, Corry JE, On SL. Identification of unusual Campylobacter-like isolates from poultry products as Helicobacter pullorum. J Appl Microbiol 1998;84:1017-24

22 Steinbrueckner B, Haerter G, Pelz L, et al. Discrimination of Helicobacter pullorum and Campylobacter lari by analysis of whole cell fatty acid extracts. FEMS Immunol Med Microbiol 1998; 168:209-12.

23 Lawson AJ, Logan JM, O'Neill GL, et al. Large-scale survey of Campylobacter species in human gastroenteritis by PCR and PCR-enzyme-linked immunosorbent assay. J Clin Microbiol 1999;37:3860-4.

24 Shen Z, Feng Y, Dewhirst FE, et al. Coinfection with enteric Helicobacter spp. and Campylobacter spp. in cats. J Clin Microbiol $2001 ; 39: 2166-72$

25 Stanley J, Jones C, Burnens A, et al. Distinct genotypes of human and canine isolates of Campylobacter upsalensis determined by 16S rRNA gene typing and plasmid profiling. J Clin Microbiol 1994;32:1788-94

26 Gibson JR, Ferrus MA, Woodward D, et al. Genetic diversity in Helicobacter pullorum from human and poultry sources identified by an amplified fragment length polymorphism technique and pulsed-field gel electrophoresis. J Appl Microbiol 1999:87:602-10.

27 Lastovica AJ, le Roux E. Efficient isolation of campylobacteria from stools. J Clin Microbiol 2000;38:2798-9.

28 Lastovica AJ, Skirrow MB. Clinical significance of Campylobacter and related species other than Campylobacter jejuni and $C$ coli. In: Nachamkin I, Blaser M, eds. Campylobacter. Washington: ASM Press, 2000:89-120.

29 Shames B, Fox JG, Dewhirst FE, et al. Identification of widespread Helicobacter hepaticus infection in feces in commercial mouse colonies by culture and PCR assay. J Clin Microbiol 1995;33:2968-72.

30 Ochert SA, Boulter AW, Birnbaum AW, et al. Inhibitory effects of salivary fluids on PCR: potency and removal. PCR Methods Appl 1994;3:365-8.

31 Widjojoatmodjo $M N$, Fluit $A D C$, Torensma $R$, et al. The magnetic immuno polymerase chain reaction assay for direct detection of salmonellae in fecal samples. I Clin Microbiol 1992:30:3195-9.

32 Whary MT, Cline JH, King AE, et al. Monitoring sentinel mice for Helicobacter hepaticus, $H$ rodentium and $H$ bilis infection by PCR and serology. Comp Med 2000;50:436-43.

33 Fox JG, Chien CC, Dewhirst FE, et al. Helicobacter canadensis sp. nov. isolated from humans with diarrhea: an example of an emerging pathogen. J Clin Microbiol 2000;38:2546-9.
34 Young VB, Knox KA, Schaver DB. Cytolethal distending toxin sequence and activity in the enterohepatic pathogen Helicobacter hepaticus. Infect Immun 2000;68: 184-91.

35 Young VB, Chien CC, Taylor NS, et al. Cytolethal distending toxin in avian and human isolates of H pullorum. J Infect Dis 2000;182:620-3.

36 Chien CC, Taylor NS, Ge Z, et al. Identification of cdiB homologues and cytolethal distending toxin activity in enterohepatic Helicobacter spp. J Med Microbiol 2000;49:525-34.

37 Fennell CL, Totten PA, Quinn TC, et al. Characterization of Campylobacter-like organisms isolated from homosexual men. J Infect Dis 1984; 149:58-66.

38 Totten PA, Fennel CL, Tenover FC. Campylobacter cinaedi (sp. nov.) and Campylobacter fennelliae (sp. nov.): two new Campylobacter species associated with enteric disease in homosexual men. J Infect Dis 1985;151:131-9.

39 On SL, Holmes B. Classification and identification of Campylobacters and Helicobacters and allied taxanumerical analysis of phenotypic characters. Syst Appl Microbiol 1995; 18:374-90.

40 Orlicek SL, Welch DF, Kuhls TL. Septicemia and meningitis caused by Helicobacter cinaedi in a neonate. J Clin Microbiol 1993;31:569-71

41 Vandamme P, Falsen E, Pot B, et al. Identification of Campylobacter cinaedi isolated from blood and feces of children and adult females. $J$ Clin Microbiol 1990;28:1016-20.

42 Tee W, Anderson BN, Ross BC, et al. Atypical campylobacters associated with gastroenteritis. J Clin Microbiol 1987;25:1248-52

43 Flores BM, Fennell CL, Kuller L. Experimental infection of pig-tailed macaques (Macaca nemestrina) with Campylobacter cinaedi and Campylobacter fennelliae. Infect Immun 1990;58:3947-53.

44 Fox JG, Handt L, Sheppard BJ, et al. Isolation of Helicobacter cinaedi from the colon, liver and mesenteric lymph node of a rhesus monkey with chronic colitis and hepatitis. J Clin Microbiol 2001;39:1580-5

45 Fox JG, Handt L, Xu S, et al. Novel Helicobacter spp isolated from colonic tissue of rhesus monkeys with chronic idiopathic colitis. J Med Microbiol 2001;50:421-9.

46 Saunders KE, Shen Z, Dewhirst FE, et al. Novel intestinal Helicobacter species isolated from cotton-top tamarins (Saguinus oedipus) with chronic colitis. J Clin Microbiol 1999;37:146-51.

47 Stills HF, Hook RR Jr, Kinden DA. Isolation of a Campylobacter-like organism from healthy Syrian hamsters (Mesocricetus auratus). J Clin Microbiol 1989:27:2497-501.

48 Lasry S, Simon J, Marais A, et al. Helicobacter cinaedi septic arthritis and bacteremia in an immunocompetent patient. Clin Infect Dis 2000;31:201-2.

$49 \mathrm{Ng}$ VL, Hadley WK, Fennell CL, et al. Successive bacteremias with Campylobacter cinaedi" and "Campylobacter fennelliae" in a bisexual male. J Clin Microbiol 1987;25:2008-9.

50 Kemper CA, Mickelson P, Morton A, et al. Helicobacter (Campylobacter) fennelliae-like organisms as an important but occult cause of bacteremia in patient with AIDS. J Infect 1993;26:97-101.

51 Burnens AP, Stanley J, Schaad UB, et al. Novel Campylobacter-like organism resembling Helicobacter fennelliae isolated from a boy with gastroenteritis and from dogs. J Clin Microbiol 1993;31:1916-17.

52 Fox JG, Drolet R, Higgins R, et al. Helicobacter canis isolated from a dog liver with multifocal necrotizing hepatitis. J Clin Microbiol 1996;34:2479-82.

53 Stanley J, Linton D, Burens AP, et al. Helicobacter canis sp. nov., a new species from dogs: an integrated study of phenotype and genotype. $J$ Gen Microbiol 1993:139:2495-504

54 Foley JE, Marks S, Munson L, et al. Isolation of Helicobacter canis from a colony of Bengal cats with endemic diarrhea. J Clin Microbiol 1999;37:3271-5

55 Dewhirst FE, Fox JG, Mendes EN, et al. Flexispira rappini strains represent at least ten Helicobacter taxa. Int J Syst Bacteriol 2000:50:1781-7.

56 Archer JR, Romero S, Ritchie AE, et al. Characterization of an unclassified microaerophilic bacterium associated with gastroenteritis. J Clin Microbiol 1988;26:101-5.

57 Davis CP, Mulcahy D, Takeuchi A, et al. Location and description of spiral-shaped microorganisms in the normal rat cecum. Infect Immun 1972;6: 184-92.

58 Hutto DL, Wannemuehler M. A comparison of the morphologic effects of Serpulina hyodysenteriae or its beta-hemolysin in the murine cecal mucosa. Vet Pathol 1999;36:412-22.

59 Romero S, Archer JR, Hamacher ME, et al. Case report of an unclassified microaerophilic bacterium associated with gastroenteritis. J Clin Microbiol 1988:26:142-3.

60 Sorlin P, Vandamme P, Nortier J, et al. Recurrent Flexispira rappini bacteremia in an adult patient undergoing hemodialysis: case report. $J$ Clin Microbiol 1999;37:1319-23

61 Stanley J, Linton D, Burens AP, et al. Helicobacter pullorum sp. nov-genotype and phenotype of a new species isolated from poultry and from human patients with gastroenteritis. Microbiology 1994:140:3441-9.

62 Burnens AP, Stanley J, Morgenstern R, et al. Gastroenteritis associated with Helicobacter pullorum. Lancet 1994;344:1569-70.

63 Steinbrueckner B, Haerter G, Pelz K, et al. Isolation of Helicobacter pullorum from patients with enteritis. Scand J Infect Dis 1997;29:315-18.

64 Lara-Tejero M, Galan JE. A bacterial toxin that controls cell cycle progression as a deoxyribonuclease I-like protein. Science 2000;290:354-7.

65 Elwell CA, Dreyfus LA. DNase I homologous residues in CdtB are critical for cytolethal distending toxin-mediated cell cycle arrest. Mol Microbiol 2000;37:952-63. 
66 Melito PL, Munro C, Chipman PR, et al. Helicobacter winghamensis sp. nov., a novel Helicobacter isolated from patients with gastroenteritis. $J$ Clin Microbiol 2001;39:2412-17.

67 Cimolai N, Gill M, Jones A, et al. "Campylobacter cinaedi" bacteremia: case report and laboratory findings. J Clin Microbiol 1987;25:942-3

68 Quinn TC, Goodell SE, Fennell CL, et al. Infections with Campylobacter jejuni and Campylobacter-like organisms in homosexual men. Ann Intern Med 1984;101:187-92.

69 Quinn TC, Stamm WE, Goodell SE, et al. The polymicrobial origin of intestinal infections in homosexual men. N EnglJ Med 1983;309:576-82

70 Mammen MP Jr, Aronson NE, Edenfield WJ, et al. Recurrent Helicobacter cinaedi bacteremia in a patient infected with human immunodeficiency virus: case report. Clin Infect Dis 1995;21:1055.

71 Sullivan AK, Nelson MR, Walsh J, et al. Recurrent Helicobacter cinaed cellulitis and bacteremia in a patient with HIV infection. Int J STD AIDS 1997;8:59-60

72 Tee W, Street AC, Spelman D, et al. Helicobacter cinaedi bacteremia: varied clinical manifestations in three homosexual males. Scand J Gastroenterol 1996;28:199-203.

73 Burman WJ, Cohn DL, Reves RR, et al. Multifocal cellulitis and monoarticular arthritis as manifestations of $\mathrm{H}$ cinaedi bacteremia. Clin Infect Dis 1995;20:564-70.

74 Flores BM, Fennell CL, Holmes KK, et al. In vitro susceptibilities of Campylobacter-like organisms to twenty antimicrobial agents. Antimicrob Agents Chemother 1985;28:188-91.

75 Sacks LV, Labriola AM, Gill VJ, et al. Use of ciprofloxacin for successful eradication of bacteremia due to Campylobacter cinaedi in a human immunodeficiency virus-infected person. Rev Infect Dis 1991;13:1066-8.

76 Trivett-Moore NL, Rawlinson WD, Yuen M, et al. Helicobacter westmeadii sp. nov., a new species isolated from blood cultures of two AIDS patients. J Clin Microbiol 1997;35:1 144-50.

77 Vandamme P, Harrington CS, Jalava K, et al. Misidentifying helicobacters: the Helicobacter cinaedi example. J Clin Microbio 2000;38:2261-6.

78 Orlicek SL, Welch DF, Kuhls TL. Helicobacter fennelliae bacteremia in a child with leukemia. Infect Dis Clin Pract 1994;3:450-1.

79 Hsueh P-R, Teng L, Hung C-C, et al. Septic shock due to Helicobacter fennelliae in non-human immunodeficiency virus-infected heterosexual patient. J Clin Microbiol 1999;37:2084-6.

80 Tee W, Leder K, Karroum E, et al. Flexispira rappini bacteremia in a child with pneumonia. J Clin Microbiol 1998;36:1679-82

81 Cuccherini B, Chua K, Gill V, et al. Bacteremia and skin/bone infections in two patients with X-linked agammaglobulinemia caused by an unusual organism related to Flexispira/Helicobacter species. Clin Immunol 2000;97: 121-9

82 Weir S, Cuccherini B, Whitney AM, et al. Recurrent bacteremia caused by a "Flexispira"-like organism in a patient with X-linked (Bruton's) agammaglobulinemia. J Clin Microbiol 1999:37:2439-45.

83 Fox JG, Dewhirst FE, Shen Z, et al. Hepatic Helicobacter species identified in bile and gallbladder tissue from Chileans with chronic cholecystitis. Gastroenterology 1998;114:755-63.

84 Rudi J, Rudy A, Maiwald M, et al. Helicobacter sp are not detectable in bile from German patients with biliary disease. Gastroenterology 1999;116:1016-17

85 Fox JG, Shen Z, Feng Y, et al. Hepatobiliary Helicobacter spp identified from patients with primary sclerosing cholangitis. Gastroenterology 1998;114:A978.

86 Nilsson HO, Taneera J, Castedal M, et al. Identification of Helicobacter pylori and other Helicobacter species by PCR, hybridization, and partial DNA sequencing in human liver samples from patients with primary sclerosing cholangitis or primary biliary cirrhosis. J Clin Microbiol 2000;38:1072-6.

87 Nilsson I, Lindgren S, Erickssons S, et al. Serum antibodies to Helicobacter hepaticus and Helicobacter pylori in patients with chronic liver disease. Gut 2000;46:410-14.

88 Mendez-Sanchez N, Pichardo R, Gonzalez J, et al. Lack of association between Helicobacter sp colonization and gallstone disease. J Clin Gastroenterol 2001;32:138-41.

89 Avenaud P, Marais A, Monteiro L, et al. Detection of Helicobacter species in the liver of patients with and without primary liver carcinoma. Cancer 2000;89:1431-9.

90 Nilsson HO, Mulchandani R, Tranberg KG, et al. Helicobacter species identified in liver from patients with cholangiocarcinoma and hepatocellular carcinoma. Gastroenterology 2001;120:323-4.

91 Stolte M, Wellens E, Bethke B, et al. Helicobacter heilmannii (formerly Gastrospirillum hominis) gastritis: An infection transmitted by animals? Scand J Gastroenterol 1994;29:1061-4.

92 Eaton KA, Radin N, Kramer L, et al. Epizoonotic gastritis associated with gastric spiral bacilli in cheetahs (Acinonyx jubatus). Vet Pathol 1993;30:55-63

93 Henry GA, Long PH, Burns JL, et al. Gastric spirillosis in beagles. Am J Vet Res 1987;48:831-6.
94 Queiroz DM, Rocha GA, Mendes E, et al. A spiral microorganism in the stomach of pigs. Vet Microbiol 1990;24:199-204.

95 Otto G, Hazell SH, Fox JG, et al. Animal and public health implications of gastric colonization of cats by Helicobacter-like organisms. J Clin Microbiol 1994;32:1043-9.

96 Sato T, Takeuchi TA. Infection by spirilla in the stomach of the rhesus monkey. Vet Pathol 1982;19:17-25.

97 Hanninen ML, Jalava K, Saari S, et al. Culture of "Gastrospirillum" from gastric biopsies of dogs. Eur J Clin Microbiol 1995;14:145-6.

98 Andersen LP, Norgaard A, Holck S, et al. Isolation of Helicobacter heilmanni-like organism from the human stomach. Eur J Clin Microbiol Infect Dis 1996;15:95-6.

99 Hilzenrat N, Lamoureux E, Weintrub I, et al. Helicobacter heilmannii-like spiral bacteria in gastric mucosal biopsies. Arch Pathol Lab Med 1995;119:1149-53.

100 Morgner A, Lehn N, Andersen LP, et al. Helicobacter heilmannii-associated primary gastric low-grade MALT lymphoma: complete remission after curing the infection. Gastroenterology 2000;118:821-8.

101 Thomson MA, Storey P, Greer R, et al. Canine-human transmission of Gastrospirillum hominis. Lancet 1994;343: 1605-7.

102 Morris A, Ali MR, Thomson L, et al. Tightly spiral shaped bacteria in the human stomach: Another cause of active chronic gastritis? Gut 1990;31:139-43.

103 Yali Z, Yamada M, Wen M, et al. Gastrospirillum hominis and Helicobacter pylori infection in Thai individuals: comparison of histopathological changes of gastric mucosa. Pathol Int 1998;48:507-1 1

104 Yang H, Goliger JA, Song M, et al. High prevalence of Helicobacter heilmannii infection in China. Dig Dis Sci 1998;43:1493

105 Stolte M, Kroher G, Meining A, et al. A comparision of Helicobacter pylori and $H$. heilmannii gastritis. A matched control study involving 404 patients. Scand J Gastroenterol 1997;32:28-33.

106 Debongnie JC, Donnay M, Mairesse J, et al. Gastric ulcers and Helicobacter heilmannii. Eur J Gastroenterol Hepatol 1998;10:251-4.

107 Akin OY, Tsou VM, Werner AL. Gastrospirillum hominis-associated chronic active gastritis. Pediatr Pathol Lab Med 1995;15:429-35.

108 Drewitz DJ, Shub MD, Ramirez FC. Gastrospirillum hominis gastritis in a child with celiac sprue. Dig Dis Sci 1997;42:1083-6.

109 Oliva MM, Lazenby AJ, Perman JA. Gastritis associated with Gastrospirillum hominis in children in children. Comparison with Helicobacter pylori and review of the literature. Mod Pathol 1993;6:513-15.

110 Tanaka MA, Saitoh T, Narita T, et al. Gastrospirillum hominis-associated gastritis: the first reported case in Japan. J Gastroenterol 1994;29:199-202.

111 Yang $H$, Dixon MF, Li $X$, et al. Acute gastritis associated with infection of large spiral-shaped bacteria. Am J Gastroenterol 1995;90:307-9.

112 Regimbeau C, Karsenti D, Durand V, et al. Low-grade gastric MALT yymphoma and Helicobacter heilmannii (Gastrospirillum hominis). Gastroenterol Clin Biol 1998;22:720-3.

113 Roggero E, Zucca E, Pinotti G, et al. Eradication of Helicobacter pylori infection in primary low-grade gastric lymphoma of mucosa associated lymphoid tissue. Ann Intern Med 1995;122:767-9.

114 Hussell T, Isaacson PG, Crabtree JE, et al. Helicobacter pylori-specific tumour-infiltrating $T$ cells provide contact dependent help for the growth of malignant B cells in low-grade gastric lymphoma of mucosa-associated lymphoid tissue. J Pathol 1996;178:122-7.

115 Goddard AF, Logan RPH, Atherton JC, et al. Healing of duodenal ulcer after eradication of Helicobacter heilmannii. Lancet 1997:349:1815-16.

116 Mendes EN, Queiroz DMM, Dewhirst FE, et al. Are pigs a reservoir host for human Helicobacter infection? Am J Gastroenterol 1994;89:1296

117 Dieterich C, Wiesel P, Neiger R, et al. Presence of multiple "Helicobacter heilmannii" strains in an individual suffering from ulcers and in his two cats. J Clin Microbiol 1998;36:1366-70.

118 Lavelle JP, Landas S, Mitros FA, et al. Acute gastritis associated with spiral organisms from cats. Dig Dis Sci 1994;39:744-50.

119 Enno A, O'Rourke J, Braye S, et al. Antigen-dependent progression of mucosa associated lymphoid tissue (MALT)-type lymphoma in the stomach. Am J Pathol 1998;152:1625-32.

120 Yang $\mathrm{H}, \mathrm{Li}, \mathrm{X}, \mathrm{Xu} \mathrm{Z}$, et al. "Helicobacter heilmannii" infection in a patient with gastric cancer. Dig Dis Sci 1995;40:1013-14.

121 Morgner A, Bayerdörffer E, Meining A, et al. Helicobacter heilmannii and gastric cancer. Lancet 1995;346:511-12.

122 Wang T, Dangler CA, Chen C, et al. Synergistic interaction between hypergastrinemia and Helicobacter infection in a mouse model of gastric carcinoma. Gastroenterology 2000;1 18:36-47.

123 Ward JM, Fox JG, Anver MR, et al. Chronic active hepatitis and associated liver tumors in mice caused by a persistent bacterial infection with a novel Helicobacter species. J Natl Cancer Inst 1994;86:1222-7.

124 Kirkbride CA, Gates CE, Collins JE. Ovine abortion associated with an anaerobic bacterium. J Am Vet Med Assoc 1985;186:789-91. 